\title{
DERECHOS AL USO DEL AGUA Y ESTRATEGIAS DE APROPIACIÓN EN LA REGIÓN SEMIÁRIDA DE PUEBLA, MÉXICO
}

\section{RIGHTS TO WATER USE AND APPROPRIATION STRATEGIES IN THE SEMIARID REGION OF PUEBLA, MÉXICO}

\author{
Ignacio Ocampo-Fletes*, Filemón Parra-Inzunza, Á. Ernesto Ruiz-Barbosa
}

\begin{abstract}
Colegio de Postgraduados, Campus Puebla. Boulevard Forjadores de Puebla No. 205, Santiago Momoxpan, Municipio de San Pedro Cholula. 72760. Puebla, Puebla. (agroecología_iof@ yahoo.com) (fparra@colpos.mx) (aruiz@colpos.mx).
\end{abstract}

\begin{abstract}
RESUMEN
El estudio muestra las capacidades de las comunidades rurales para hacer frente a la escasez física del agua en una región semiárida del sur del estado de Puebla, México. Se analizaron las distintas fuentes de agua, el derecho a su uso y las estrategias de apropiación que han establecido los grupos sociales. Se aplicó una encuesta a 221 familias de $\mathbf{3 0}$ comunidades en nueve municipios y se realizaron transectos y talleres. Los resultados muestran que la apropiación del agua en condiciones de escasez requiere el reconocimiento del territorio para identificar las distintas fuentes de agua y la propiedad de la misma, la construcción de acuerdos locales y diferentes estrategias acordes a los recursos materiales, económicos y humanos de cada usuario. El derecho al uso del agua está relacionado con la propiedad del espacio natural (familiar o individual, comunitario o comunal y estatal) y a la propiedad de la fuente del agua (acceso privado, comunal y abierto o libre). Se concluye que la escasez física del agua ha obligado a los grupos humanos a reconocer su espacio físico y ecológico, y a desarrollar diferentes estrategias para apropiarse de un recurso al que tienen derecho.
\end{abstract}

Palabras clave: derechos de uso, estrategias de apropiación, fuentes de agua, región mixteca.

\section{INTRODUCCIÓN}

$\mathrm{E}$ 1 agua es un recurso natural indispensable para la vida de todos los seres vivos que se compara con la vida misma. Para los seres humanos es la base de la vida y su desarrollo, por lo que se ha declarado como un derecho humano (Naciones Unidas, 1948; Naciones Unidas, 2002; Naciones Unidas,

* Autor responsable * Author for correspondence.

Recibido: enero, 2015. Aprobado: agosto, 2016.

Publicado como ARTíCULO en ASyD 15: 63-83. 2018.

\section{Abstract}

The study shows the capacities of rural communities to face the physical scarcity of water in a semiarid region of the south of the state of Puebla, México. The different sources of water were analyzed, as well as the right to their use and the appropriation strategies that social groups have established. A survey was applied to 221 families from 30 communities in nine municipalities, and transects and workshops were carried out. The results show that water appropriation under conditions of scarcity requires the recognition of the territory to identify the different sources of water and the water's property, the construction of local agreements, and different strategies according to the material, economic and human resources of each user. The right to use water is related to the property of the natural space (family or individual, community or communal, and state) and to the property of the water source (private, communal and open or free access). It is concluded that the physical scarcity of water has forced human groups to recognize their physical and ecological space, and to develop different strategies to take over a resource that they have the right to.

Key words: rights of use, appropriation strategies, water sources, Mixteca region.

\section{INTRODUCTION}

W ater is an essential natural resource for the life of all living beings that is compared to life itself. For human beings, it is the basis of life and its development, which is why it has been declared as a human right (Naciones Unidas, 1948; Naciones Unidas, 2002; Naciones Unidas, 2010a). However, it has been recognized that humanity faces a problem of scarcity caused by the physical lack of water available to satisfy the demand, the insufficient 
2010a). Sin embargo, se ha reconocido que la humanidad enfrenta un problema de escasez causada por la falta física de agua disponible para satisfacer la demanda, la insuficiente infraestructura de almacenamiento, distribución y acceso, y la incapacidad de las instituciones para aportar los servicios necesarios (FAO, 2013).

Naciones Unidas en su informe de 2013 (objetivo 7, meta 7.C) reportó que en 2011 había 768 millones de personas utilizando agua de fuentes no mejoradas, la mayor parte (636 millones) del medio rural, y $38 \%$ de los 6200 millones de personas que usaban fuentes mejoradas de agua potable no contaban con agua potable por tubería, por lo que dedicaban tiempo y energía para acarrear el agua y satisfacer las necesidades esenciales; 180 millones de personas seguían recurriendo a ríos, arroyos, estanques o lagos para acarrear el agua y satisfacer sus necesidades diarias (Naciones Unidas, 2013).

El derecho al acceso, disposición y saneamiento de agua para consumo personal y doméstico en forma suficiente, salubre, aceptable y asequible fueron reconocidas por el estado mexicano en febrero de 2012, reformando el Artículo $4^{\text {o }}$ de la Constitución Política de los Estados Unidos Mexicanos, decretando que el Estado garantizará el derecho al agua y definirá las bases, apoyos y modalidades para el acceso y uso equitativo y sustentable, estableciendo la participación de la Federación, las entidades federativas, los municipios y la ciudadanía (DOF, 2012).

México ocupaba el lugar 74 respecto a crisis de agua de 174 países estudiados por el Centro para la Ecología e Hidrología de Gran Bretaña, con una disponibilidad de 4900 metros cúbicos per cápitalaño (Saldivar, 2007). Para 2012 se reportó que $95 \%$ de la población tuvo acceso a fuentes de agua potable mejorada y $5 \%$ careció de esta. En la población rural la proporción fue de $91 \%$ y $9 \%$, respectivamente (OMS y UNICEF, 2014). Para 2010, en el estado de Puebla se registró una población con servicio de agua entubada de $88.1 \%$ y el resto sin servicio (INEGI, 2016).

Para miles de personas el acceso al agua potable sigue siendo difícil. En algunas regiones las demandas son mayores que la disponibilidad y el agua no está garantizada para todos. El panorama se presenta más crítico para las zonas áridas, donde la escasez se asocia a escasez física y no hay agua suficiente para satisfacer las demandas de la población. Como síntomas infrastructure for storage, distribution and access, and the inability of institutions to provide the necessary services (FAO, 2013).

United Nations in its 2013 report (objective 7, goal 7.C) reported that in 2011 there were 768 million people using water from unsanitized sources, the greatest part (636 million) from rural areas, and $38 \%$ of the 6200 million people who used sanitized drinking water sources did not have piped drinking water, which is why they devoted time and energy to transport water and satisfy essential needs; 180 million people continue resorting to rivers, streams, ponds or lakes to transport water and satisfy their daily needs (Naciones Unidas, 2013).

The right to access, availability and sanitation of water for personal and domestic consumption in a sufficient, healthy, acceptable and affordable manner was recognized by the Mexican state in February of 2012, reforming Article 4 of the Political Constitution of México, ordaining that the State would guarantee the right to water and define the bases, supports and modalities for access and equitable and sustainable use, establishing the participation of the Federation, the federal entities, municipalities and citizens (DOF, 2012).

México occupied place 74 in regard to water crisis out of 174 countries studied by the Center for Ecology and Hydrology of Great Britain, with an availability of 4900 cubic meters per capitalyear (Saldivar, 2007). For 2012 it was reported that $95 \%$ of the population had access to sources of sanitized drinking water and $5 \%$ lacked it. In the rural population the proportion was $91 \%$ and $9 \%$, respectively (OMS and UNICEF, 2014). For 2010, a population with piped water services of $88.1 \%$ was found in the state of Puebla and the rest without service (INEGI, 2016).

For thousands of people access to drinking water continues to be difficult. In some regions the demands are higher than the availability and water is not guaranteed for everyone. The panorama is more critical for arid zones, where the scarcity is associated to physical scarcity and there is not enough water to satisfy the demands of the population. As symptoms of physical scarcity, there are environmental degradation, decrease of underground water volumes, and unequal allocation between groups (IWMI and FAO, 2007; FAO, 2013).

The consequences of the scarcity are suffered most by the population in poverty; the effort of supplying 
de la escasez física están la degradación ambiental, disminución de los volúmenes de agua subterránea y la asignación desigual entre grupos (IWMI y FAO, 2007; FAO, 2013).

Las consecuencias de escasez las sufren más la población en pobreza; en las mujeres recae el esfuerzo de abastecer agua, los nińos y ancianos son más vulnerables a enfermedades (Hernández y Herrerías, 2004). En el territorio mexicano dos terceras partes se consideran áridas o semiáridas, con precipitaciones menores a los $50 \mathrm{~mm}$ (SEMARNAT y CONAGUA, 2013).

La región mixteca baja de Puebla, México está ubicada en una zona semiárida con una condición de escasez física del agua ${ }^{1}$ donde los pobladores tienen que acceder $y$ apropiarse del agua en condiciones difíciles impuestas por el ambiente natural, y los ha estimulado a establecer diferentes prácticas de localización de las fuentes en el territorio, acceder al recurso, lograr el abasto y su aprovechamiento (Ocampo y Villarreal, 2014), y construir y respetar reglas para tener derechos al agua para satisfacer sus necesidades.

Basado en lo anterior se planteó este estudio con dos objetivos: i) identificar las distintas fuentes de agua y el derecho a su uso por los grupos sociales y, ii) analizar las estrategias adoptadas por los habitantes para acceder, apropiarse y usar el agua para su desarrollo personal y familiar.

El estudio se abordó con un enfoque de relación sociedad-naturaleza basado en los vínculos que establece el hombre para apropiarse de los recurso naturales. Para satisfacer sus necesidades los seres humanos realizan intercambios con la naturaleza y entre ellos mismos; ya sean intercambios considerando a los seres humanos como seres biológicos, es decir, materiales, que se realizan con el universo natural (enfoque ecológico), o reconociendo al hombre como un ente social, o sea, que realizan entre ellos mismos (enfoque económico) (Toledo, 2008).

En este proceso existen diferentes mecanismos, procesos y relaciones sociales que afectan la capacidad de la gente para beneficiarse de los recursos. Pueden ser aspectos culturales, políticos y económicos constituidos en redes de poder para el acceso a los recursos, además del posicionamiento que tienen las personas e instituciones en los distintos momentos históricos y escalas geográficas (Ribot y Peluso, 2003).

En muchas zonas rurales, los pobres dependen casi exclusivamente de su capacidad para acceder y utilizar los recursos naturales como base de sus medios de water falls on women, and children and the elderly are more vulnerable to diseases (Hernández and Herrerías, 2004). In the Mexican territory two thirds are considered arid or semiarid, with precipitations below $50 \mathrm{~mm}$ (SEMARNAT and CONAGUA, 2013).

The low Mixteca region in Puebla, México, is located in a semiarid zone with a condition of physical scarcity of water ${ }^{1}$ where the inhabitants tend to have access and appropriate water under difficult conditions imposed by the natural environment, and this has stimulated them to establish different practices of localization of the sources in the territory, having access to the resource, attaining the supply and its exploitation (Ocampo and Villarreal, 2014), and building and respecting rules to have rights to water to satisfy their needs.

Based on this, the study was set out with two objectives: i) identifying the different sources of water and the right to its use by social groups, and ii) analyzing the strategies adopted by inhabitants to have access, appropriate and use water for their personal and family development.

The study was addressed with an approach of society-nature relationship based on the links that man establishes to appropriate natural resources. In order to satisfy their needs, human beings carry out exchanges with nature and among themselves; whether they are exchanges considering human beings as biological beings, that is, material, which are performed with the natural universe (ecological approach), or recognizing man as a social being, that is, which are performed between themselves (economic approach) (Toledo, 2008).

In this process there are different mechanisms, processes and social relations that affect the capacity of people to benefit from the resources. There can be cultural, political and economic aspects built into networks of power for access to the resources, in addition to the positioning that people and institutions have at different historical moments and geographic scales (Ribot and Peluso, 2003).

In many rural zones, poor people depend almost exclusively on their capacity to gain access and use natural resources as a basis for their livelihoods; in this case, access to water is something key for health and defining of other resources such as plants and animals from the local ecosystems (PovertyEnvironment Partnership, 2006). 
vida; en este caso, el acceso al agua es clave para la salud y determinante de otros recursos como las plantas y animales de los ecosistemas locales (Poverty-Environment Partnership, 2006).

El acceso es la capacidad de beneficiarse de objetos materiales, personas, instituciones y símbolos. La capacidad implica un conjunto de relaciones sociales que permiten a la gente beneficiarse de recursos, utilizando todos los medios posibles (Ribot y Peluso, 2003). El acceso a través de la identidad social afecta profundamente la distribución de los beneficios. En una comunidad o grupo es a menudo mediado por la identidad social o la pertenencia, incluyendo agrupaciones por edad, género, etnia, religión, estado, profesión, lugar de nacimiento, la educación común, u otros atributos que constituyen a la identidad social (Moore 1986 citado en Ribot y Peluso, 2003).

En los recursos de uso común -"sistema de recursos naturales o creados por el hombre"-, "el acceso puede limitarse a un solo individuo o empresa, o bien, a múltiples individuos o grupos de individuos que usan el sistema de recursos simultáneamente". Para su apropiación (proceso de sustracción del recurso) se adoptan normas internas, utilizando estrategias contingentes e independientes para relacionarse entre sí. Las contingentes son todas las acciones planeadas que están supeditadas al mundo exterior; cada apropiador acepta seguir un conjunto de reglas con la condición de que los otros cumplan para el beneficio de todos (Ostrom, 2011: 77-78, 87, 177).

Las acciones dependen de la propiedad del recurso. "La propiedad es una maraña de derechos para controlar el uso de los recursos" (CiriacyWantrup, 1995: 42). En la "propiedad de acceso abierto" todos los propietarios hacen uso del recurso; en la "propiedad comunitaria o comunal", todos los propietarios tienen derecho a usar el recurso natural y si este no se usa, no se pierde. En este tipo de propiedad se puede llegar al abuso de los recursos si no se respetan las reglas establecidas, aunque este no sea el origen del problema ambiental, sino el sometimiento de los recursos a una lógica comercial, surgiendo una presión sobre los recursos que adquieren un valor de uso. La "propiedad privada" tiene un horizonte temporal a corto plazo, por lo que se valora por la relación costo beneficio que recae en el propietario y deben conservar los recursos naturales. En este sentido, la propiedad comunitaria es más duradera que la
Access is the capacity of benefiting from material objects, people, institutions and symbols. The capacity implies a set of social relationships that allow people to benefit from resources, using all the means possible (Ribot and Peluso, 2003). Access through social identity affects deeply the distribution of benefits. In a community or group it is often mediated by the social identity or belonging, including grouping per age, gender, ethnicity, religion, state, profession, place of birth, common education, or other attributes that constitute social identity (Moore 1986 cited in Ribot and Peluso, 2003).

In resources of common use -"systems of natural resources or created by man"-, "access can be limited to a single individual or company, or else, to multiple individuals or groups of individuals that use the system of resources simultaneously". For their appropriation (process of extraction of the resource), internal norms are adopted, using contingent and independent strategies to relate among themselves. The contingencies are all the actions planned that are dependent on the external world; each appropriator accepts following a set of rules with the condition of others complying for the benefit of all (Ostrom, 2011: 77-78, 87, 177).

Actions depend on the property of the resource. "Property is a tangled mess of rights to control the use of resources" (Ciriacy-Wantrup, 1995: 42). In the "open access property" all owners make use of the resource; in the "community or communal property", all the owners have the right to use the natural resource and if it is not used, it is not lost. In this type of property there can be abuse of resources if the rules established are not respected, although this is not the origin of the environmental problem, but rather the subjugation of resources to a commercial logic, pressure emerging on the resources that acquire a value of use. The "private property" has a short term temporal horizon, which is why it is valued for the cost-benefit relation that falls on the owner and must conserve natural resources. In this sense, community property is more lasting than private property because of the short-term horizon that the latter suggests (Martínez, 1999a: 110-111; 1999b: 33-35).

Gadgil and Iyer (1993) mention that the sustainable use of a common resource is possible under special conditions and is favored when: a) the number of groups of people who share the 
privada por el horizonte a corto plazo que plantea esta última (Martínez, 1999a: 110-111; 1999b: 3335).

Gadgil e Iyer (1993) mencionan que el uso sostenible de un recurso común es posible bajo condiciones especiales y se ve favorecido cuando: a) el número de grupos de personas que comparten el recurso es reducido; b) cuando el grupo de personas interactúan entre sí por periodos largos; c) el grupo comparte beneficios de manera equitativa; y d) los grupos de individuos se relacionan entre sí por lazos de parentesco y reciprocidad en otros contextos. Los grupos desarrollan diversos mecanismos para regular la utilización de los recursos que necesitan.

En recursos de propiedad de acceso abierto y de propiedad comunal, cada jefe de familia hace uso de los recursos equivalentes, práctica que minimiza las diferencias entre las comunidades. Esta propiedad se utiliza colectivamente aunque la extracción de los recursos esté basada en la acción individual. Cada familia utiliza ciertos recursos bajo la regulación de la comunidad (Toledo y Argueta, 1993).

En la acción colectiva los individuos actúan independientemente para obtener beneficios colectivos y los resultados dependen de variables internas, entre otras: número de personas que toman las decisiones, número de participantes para lograr un beneficio colectivo, objetivos similares y presencia de líderes (Ostrom, 2011: 165).

Respecto a los derechos al agua como expresiones de relaciones sociales definen quiénes pueden y quiénes no pueden utilizar el agua, por lo que son dinámicos y están en constantes relaciones con los actores sociales de los que se originan (Gerbrandy y Hoogendam, 1998: 84).

Con base en lo anterior, el estudio se abordó con el enfoque de los derechos locales o consuetudinarios establecidos por los actores locales que se encargan del aprovechamiento del agua, con normas específicas para el sistema y el lugar en que funcionan, y no desde el sistema jurídico legal o formal relacionado con leyes, abogados, cortes y jueces generadas desde el Estado (Gerbrandy y Hoogendam, 1998: 81-82).

Se consideran reglas consuetudinarias a las "aceptadas y usadas por comunidades locales durante mucho tiempo"; es la ley viviente de los pueblos, aunque no toda ley del pueblo es consuetudinaria porque existen también alguna que provienen de reglas oficializadas jurídicamente por los formuladores de resource is reduced; b) when the group of people interact between each other for long periods; c) the group shares benefits equitably; and d) the groups of individuals are related among themselves by links of kinship and reciprocity in other contexts. The groups develop various mechanisms to regulate the use of the resources that they need.

In resources of open access property and communal property, each head of family makes use of equivalent resources, practice that minimizes the differences between communities. This property is used collectively although the extraction of resources is based on individual action. Each family uses certain resources under the regulation of the community (Toledo and Argueta, 1993).

In collective action, individuals act independently to obtain collective benefits and the results depend on internal variables, among others: number of people who make decisions, number of participants to achieve a collective benefit, similar objectives, and presence of leaders (Ostrom, 2011: 165).

With regards to the rights to water as expressions of social relations, they define who may and who may not use the water, which is why they are dynamic and are in constant relation to the social actors that originate them (Gerbrandy and Hoogendam, 1998: 84).

Based on this, the study was addressed with the approach of local or customary rights established by local actors that are in charge of water exploitation, with specific norms for the system and place where they work, and not from the legal or formal system related to laws, lawyers, courts and judges generated from the State (Gerbrandy and Hoogendam, 1998: 81-82).

Customary rules are considered to be the ones "accepted and used by local communities for a long time"; it is the living law of peoples, although not every law of the people is customary because there are also some that come from rules that are made official by lawmakers, called customary law (Von BendaBeckmann et al., 1998).

\section{Methodology}

The study area belongs to the low Mixteca region in the state of Puebla; it covers a surface of 1677.6 $\mathrm{km}^{2}$ (INAFED, 2010) where 235 communities are settled (INEGI, 2009) and a population of 43622 
leyes, denominado derecho consuetudinario (Von Benda-Beckmann et al., 1998).

\section{Metodología}

El área de estudio pertenece a la región mixteca baja del estado de Puebla; comprende una superficie de $1677.6 \mathrm{~km}^{2}$ (INAFED, 2010) en las que se encuentran asentadas 235 comunidades (INEGI, 2009) y una población de 43622 habitantes (INEGI, 2010), con densidad de población entre 8 y 31 habitantes por kilómetro cuadrado y tasas de crecimiento decrecientes (CONAGUA, 2010). Dentro de esta se estudiaron 30 comunidades de nueve municipios (Cuadro 1), seleccionadas por su condición de alta marginación social para participar en el Proyecto Estratégico de Seguridad Alimentaria (PESA) implementado por el gobierno federal (Secretaría de Agricultura, Ganadería, Desarrollo Rural, Pesca y Alimentación-SAGARPA) y el gobierno estatal (Secretaría de Desarrollo Rural-SDR), con colaboración de la Organización de las Naciones Unidas para la Agricultura y la Alimentación (FAO).

La zona de estudio se ubica entre los paralelos $17^{\circ} 06^{\prime}$ y $18^{\circ} 30^{\prime} \mathrm{N}$ y $97^{\circ} 50^{\prime}$ y $98^{\circ} 33^{\prime} \mathrm{O}$. Se presentan tres tipos de climas: $\mathrm{Aw} 0(\mathrm{w})$ cálido subhúmedo con lluvias en verano, $\left(\mathrm{BS} 1\left(\mathrm{~h}^{\prime}\right) \mathrm{w}(\mathrm{w})\right.$ semiseco, muy cálido y cálido (BS1(h') w(w), y A(C)w0(w) semicálido subhúmedo con lluvias en verano. La altura sobre el nivel del mar fluctúa entre los 700 y 1200 metros, con precipitaciones entre 600 y $1000 \mathrm{~mm}$, temperaturas entre 20 y $26^{\circ} \mathrm{C}$ y suelos leptosoles, regosoles, phaeozem y vertisoles (INEGI, 2009).

Para generar datos cuantitativos se utilizó la encuesta aplicando un cuestionario estructurado a 221 jefes y jefas de familia (92 hombres y 129 mujeres) inhabitants (INEGI, 2010), with population density of between 8 and 31 inhabitants per kilometer squared and decreasing growth rates (CONAGUA, 2010). Within it, 30 communities from nine municipalities were studied (Table 1), selected for their condition of high social marginalization to participate in the Strategic Food Security Project (Proyecto Estratégico de Seguridad Alimentaria, PESA) implemented by the federal government (Minstry of Agriculture, Livestock Production, Rural Development, Fishing and Food, Secretaria de Agricultura, Ganadería, Desarrollo Rural, Pesca y Alimentación-SAGARPA) and the state government (Ministry of Rural Development, Secretaria de Desarrollo Rural-SDR), with the collaboration by the Food and Agriculture Organization of the United Nations (FAO).

The study zone is located between parallels $17^{\circ} 06^{\prime}$ and $18^{\circ} 30^{\prime} \mathrm{N}$ and $97^{\circ} 50^{\prime}$ and $98^{\circ} 33^{\prime} \mathrm{W}$. Three types of climate are present: $\mathrm{Aw} 0(\mathrm{w})$ warm subhumid with summer rains, (BS1(h')w(w) semidry, very warm and warm $\left(\mathrm{BS} 1\left(\mathrm{~h}^{\prime}\right) \mathrm{w}(\mathrm{w})\right.$, and $\mathrm{A}(\mathrm{C})$ w0(w) semi-warm sub-humid with summer rains. The altitude over sea level fluctuated between 700 and 1200 meters, with precipitation between 600 and $1000 \mathrm{~mm}$, temperatures between 20 and $26{ }^{\circ} \mathrm{C}$, and Leptosol, Regosol, Phaeozem and Vertisol soils (INEGI, 2009).

To generate quantitative data the survey was used, applying a structured questionnaire to 221 heads of households (92 men and 129 women) selected from a population of 521 households that participated directly in PESA. In order to define the size of the sample, a simple random sampling without replacement was used, and for the identification of their elements random processes were used:

Cuadro 1. Municipios y comunidades del área de estudio en la Mixteca Baja Poblana.

Table 1. Municipalities and communities from the study area in the low Mixteca region of Puebla.

\begin{tabular}{ll}
\hline \multicolumn{1}{c}{ Municipio } & \multicolumn{1}{c}{ Comunidades } \\
\hline Tehuitzingo & Los Hornos de Zaragoza, Cuaulutla,Tecolutla, Tuzantlán y Atopoltitlán \\
Ahuehuetitla & Guadalupe Alchipini, Piedra Blanca y San Vicente El Peńón \\
Chinantla & San Miguel Buenavista, Cuatecontla y Amatepetlán \\
San Jerónimo Xayacatlán & Cañada Estaca, El Cuajilote y Gabino Barreda \\
San Pablo Anicano & San Miguel Tulapa, El Pedregoso y Francisco González Bocanegra \\
Tecomatlán & Mixquiapan, Xantoxtla, Tempexquixtle y Tezoquipan \\
Chila de la Sal & San Pedro Ocotlán \\
Tulcingo del Valle & La Ciénega, Guadalupe Tulcingo, Aguacatitlán y Francisco Villa \\
Piaxtla & Loma Bonita, Yetla, Santa María y Atempa \\
\hline
\end{tabular}


seleccionadas de una población de 521 hogares que participaron directamente en el PESA. Para determinar el tamaño de muestra se utilizó el muestreo simple aleatorio sin reemplazo y para la identificación de sus elementos se utilizaron procesos aleatorios:

$$
n=\frac{N Z_{\alpha / 2}^{2} p_{n} q_{n}}{N d^{2}+Z_{\alpha / 2}^{2} p_{n} q_{n}}
$$

donde $n$ : tamaño de muestra (221); $N$ : tamaño de la población (521); d: precisión $0.05, Z_{\alpha / 2}: 95 \%$ confiabilidad; $p_{n}=0.5 ; q_{n}=0.5$.

Se utilizaron dos técnicas cualitativas, utilizando la guía de entrevista: 1) el transecto (entrevista grupal) por las comunidades, sus campos y barrancas para identificar las fuentes de agua, los sistemas de conducción y los depósitos de almacenamiento; y 2) talleres de análisis en las que participaron hombres y mujeres de diferentes edades para analizar la situación del agua y las estrategias de gestión. La técnica cuantitativa y las cualitativas se complementaron para explicar los procesos sociales que ocurren en torno a la localización, acceso, abastecimiento, almacenamiento y usos del agua en el espacio-temporal, por lo que fue necesario estar dentro del proceso. La información registrada en el cuestionario se organizó y procesó para su análisis con el programa estadístico Statistical Package for the Social Science (SPSS). La información cualitativa se registró en libreta de campo y hojas de rotafolio.

\section{Resultados y Discusión}

\section{La hidrología de la región}

El área de estudio se encuentra dentro la Región Hidrológica No. IV Balsas, subregión Alto Balsas. La mayor parte de la superficie forma parte de la Cuenca del Río Atoyac y una menor parte del Río Tlapaneco, dentro de la subcuenca de los ríos: Mixteco, Acatlán, Atoyac-Tehuitzingo y Salado (INEGI, 2009) (Figura 1).

En su recorrido, el río Atoyac recibe aguas de los ríos Mixteco, Acatlán y Tizac. Existe un cuerpo de agua perenne, llamado Boqueroncitos. Las corrientes de agua perennes que fluyen por el territorio son los ríos Atoyac, Mixteco, Acatlán y Tecoloyan, y los

$$
n=\frac{N Z_{\alpha / 2}^{2} p_{n} q_{n}}{N d^{2}+Z_{\alpha / 2}^{2} p_{n} q_{n}}
$$

where $n$ : size of the sample $(221) ; N$ : size of the population (521); d: accuracy $0.05, Z_{\alpha / 2}: 95 \%$ reliability; $p_{n}=0.5 ; q_{n}=0.5$.

Two qualitative techniques were used, following the interview guide: 1) transect (group interview) by communities, their fields and ravines, to identify the water sources, conduction systems, and storage deposits; and 2) analysis workshops where men and women of different ages participated to analyze the situation of water and the management strategies. The quantitative and qualitative techniques were complemented to explain the social processes that take place around localization, access, supply, storage and uses of water in time and space, so it was necessary to be inside the process. The information recorded in the questionnaire was organized and processed for its analysis with the statistical software Statistical Package for the Social Science (SPSS). The qualitative information was recorded in a field notebook and flip chart paper.

\section{Results AND Discussion}

\section{Hydrology of the region}

The study area is located inside the Hydrologic Region No. 4 Balsas, sub-region Alto Balsas. Most of the surface is part of the Atoyac River Basin, and a smaller part of the Tlapaneco River, inside the sub-basin of the rivers Mixteco, Acatlán, AtoyacTehuitzingo and Salado (INEGI, 2009) (Figure 1).

Through its path, the Atoyac River receives waters from the rivers Mixteco, Acatlán and Tizac. There is a permanent body of water, called Boqueroncitos. The permanent water currents that flow through the territory are rivers Atoyac, Mixteco, Acatlán and Tecoloyan, and the intermittent: El Chilsolote, Laguna Seca, La Trompeta, Tizac, Valiente, Paredón, Tulapa and El Chahuate (INEGI, 2009). There are several temporary tributaries of less importance. However, the region is considered as water deficient, particularly during the months of March, April and May, period when both superficial and underground water resources are scarce. 


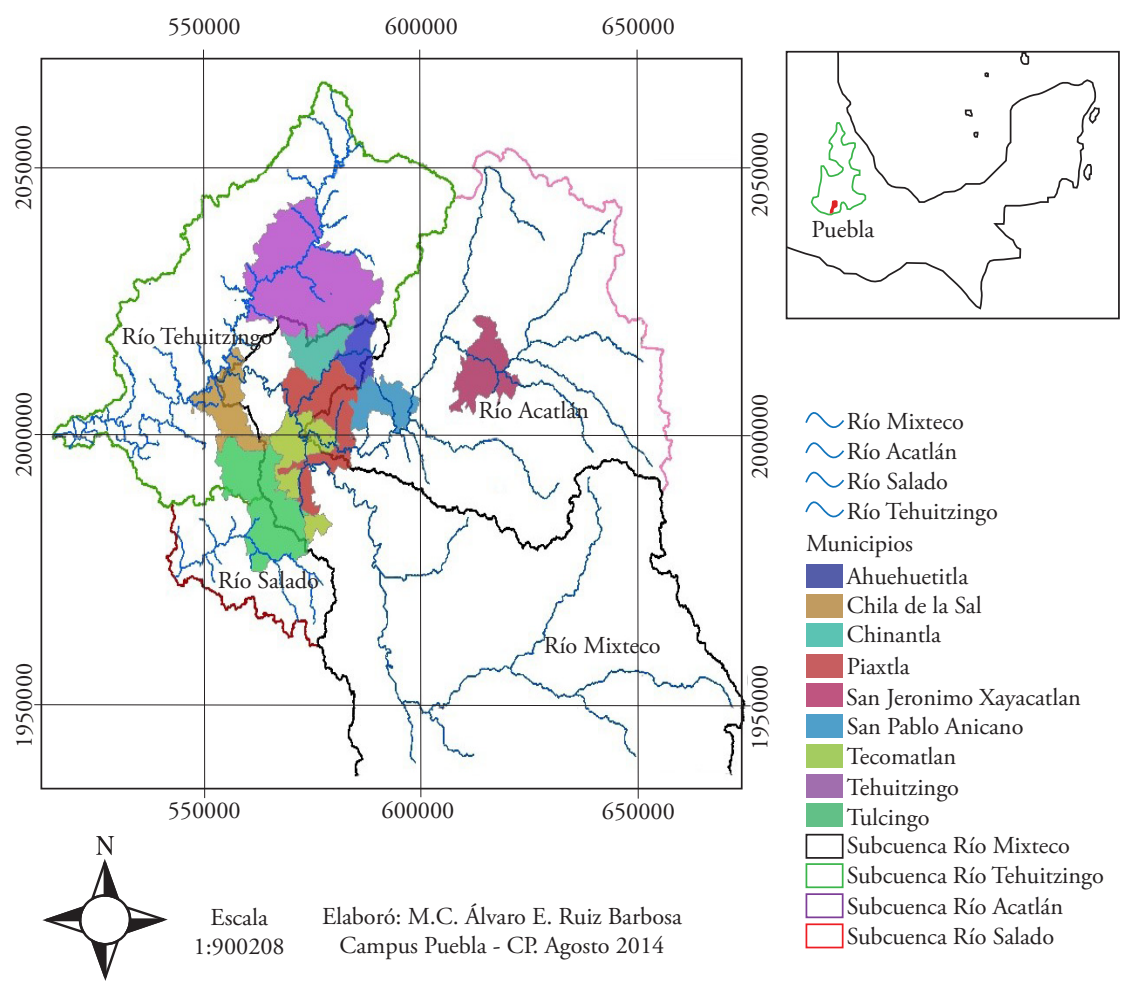

Fuente: elaboración de Ruíz Barbosa A. E. con información de INEGI, 2013. Marco geoestadístico del estado de Puebla. \&ource: elaborated by Ruíz Barbosa A. E. with information from INEGI, 2013. Geostatistical framework of the state of Puebla.

Figura 1. Localización de las subcuencas, principales ríos y municipios de la zona de estudio en la mixteca baja poblana.

Figure 1. Localization of sub-basins, main rivers and municipalities of the study zone in the low Mixteca region of Puebla.

intermitentes: El Chilsolote, Laguna Seca, La Trompeta, Tizac, Valiente, Paredón, Tulapa y El Chahuate (INEGI, 2009). Existen varios afluentes temporales de menor importancia. Sin embargo, la región es considerada como deficiente de agua, sobre todo en los meses de marzo, abril y mayo, periodo en que escasean tanto los recursos hídricos superficiales como los subterráneos.

\section{Fuentes, derechos de propiedad, acceso y usos del agua}

En el caso estudiado, al interior de cada municipio y comunidad existen diferentes fuentes de agua. Las obras (infraestructura) para su captación dependen del tipo de fuente de agua, de la ubicación en el territorio y de los recursos disponibles.

Los apropiadores de los recursos de uso común se auto organizan para gobernar y administrar el recurso, por lo que diseñan, implementan y hacen cumplir el conjunto de reglas acordadas para la provisión

\section{Sources, property rights, access and uses of water}

In the case studied, inside each municipality and community there are different sources of water. The works (infrastructure) for its capture depend on the type of water source, on the location in the territory and on the available resources.

The appropriators of resources of common use self-organize to rule and manage the resource, which is why they design, implement and enforce the set of rules agreed upon for the provision of the local collective good (Ostrom, 2011:81). In the 30 communities with water sources of community or communal property, for water management and works, there are committees in charge of distributing water, watching over the good functioning and conservation of the infrastructure, and managing the economic resources from the service. 
del bien colectivo local (Ostrom, 2011:81). En las 30 comunidades con fuentes de agua de propiedad comunitaria o comunal, para la administración del agua y la obra existen comités encargados de distribuir el agua, vigilar el buen funcionamiento y la conservación de la infraestructura, y administrar recursos económicos por servicio.

Para mantener el funcionamiento de la fuente de propiedad común existen lazos mutuos de obligaciones y de participación colectiva en la que cada usuario se identifica con el colectivo por historias compartidas sobre el agua, mitos de origen y pertenencia, costumbres, rituales y luchas; la mayoría de estos derechos y reglas no están escritos, están materializados en los vínculos de obligaciones mutuas (Boelens, 2009).

Para el caso en estudio se localizan fuentes de propiedad privada y acceso individual que no requiere de acuerdos sociales, y fuentes de propiedad comunal y acceso colectivo que requiere acuerdos sociales de la comunidad y en ocasiones con mediación institucional, como sugieren Cáceres y Rodríguez (2014), frecuente en fuentes como: pozos tipo noria, pozos profundos, depósitos comunitarios, jagüeyes, bordos, presas y manantiales.

Los hallazgos muestran que en el municipio de Tehuitzingo las cinco comunidades en estudio disponen de pozos tipo noria (excavados a mano) de propiedad privada de acceso individual y propiedad comunal para los usos domésticos y para el ganado. La comunidad Atopoltitlán tiene dos depósitos comunitarios para almacenar agua de la barranca, ambos administrados por comités de agua, encargados de la conservación, distribución y buen manejo del agua.

En el municipio de Ahuehuetitla las tres comunidades tienen acceso al agua para los usos domésticos y para el ganado por medio de pozos tipo noria, pozos profundos (perforados con maquinaria), aguajes (aguaderos) y un jagüey (ollas de agua, cajas de agua o aljibes) de propiedad privada (individual) y comunal. En Guadalupe Alchipini se utilizan pequeñas áreas para la siembra con riego.

Situación muy semejante se presenta en el municipio de Chinantla; las tres comunidades tienen acceso al agua para usos doméstico y para el ganado a través de pozos profundos, pozos tipo noria y bordos para captar agua de lluvia, tanto de propiedad privada y acceso individual como de propiedad comunal. En la comunidad de Amatepetlán se localiza un pozo de agua salina que no tiene uso.
In order to maintain the functioning of the source of common property, there are mutual links of obligations and collective participation in which each user is identified with the collective by shared stories about water, myths of origin and belonging, customs, rituals and struggles; most of these rights and rules are not written, they are materialized in the links of mutual obligations (Boelens, 2009).

For the case in study, sources of private property and individual access that do not require social agreements are pinpointed, as well as sources of communal property and collective access that require social agreements in the community and, occasionally, with institutional mediation, as suggested by Cáceres and Rodríguez (2014), frequently in sources such as: wells with waterwheels, deep wells, community deposits, jagüeyes, bordos, dams and springs.

The findings show that in the municipality of Tehuitzingo the five communities of study have wells with waterwheels (dug by hand) of private property with individual access and communal property for domestic uses and for the livestock. The community of Atopoltitlán has two community deposits to store water from the ravine, both managed by water committees, in charge of the conservation, distribution and good management of water.

In the municipality of Ahuehuetitla the three communities have access to water for domestic uses, and for livestock through wells with waterwheels, deep wells (perforated with machinery), currents (aguaderos), and one jagüey (water pots, water boxes or tanks) of private property (individual) and communal. In Guadalupe Alchipini small areas are used for sowing with irrigation.

There is a very similar situation in the municipality of Chinantla; the three communities have access to water for domestic uses and for livestock through deep wells, wells with waterwheels, and bordos to capture rainwater, both of private property and individual access and of communal property. In the community of Amatepetlán there is a well of salt water that is not used.

Of the three communities in the municipality of San Jerónimo Xayacatlán, Cañada Estaca has access to more water sources by being located near the Acatlán or Tizac River, which allows it to irrigate small agricultural areas, in addition to supplying water for domestic use and for livestock production, in contrast with other communities that only have deep 
De las tres comunidades en el municipio de San Jerónimo Xayacatlán, Cañada Estaca accede a más fuentes de agua al estar localizada cerca del Río Acatlán o Tizac, lo que le permite regar pequeñas áreas agrícolas, además de abastecerse de agua para el uso doméstico y para la ganadería, a diferencia de las otras comunidades que solo cuentan con pozos profundos, pozos tipo noria y aguajes (aguaderos) de propiedad privada y propiedad comunal.

Para el abastecimiento del agua para el hogar y para el ganado en San Pablo Anicano, se hace uso de pozos profundos, pozos tipo noria, escurrimientos, una presa, jagüeyes y bordos para captar agua de lluvia, tanto de propiedad individual como de propiedad comunal.

En el municipio de Tecomatlán las cuatro comunidades en estudio tienen una ubicación privilegiada en los márgenes de los Ríos Acateco y Mixteco, lo que además permite un buen abastecimiento de agua para uso doméstico, para el ganado y la siembra de cultivos de riego en los márgenes de ambos ríos, utilizando pozos y bombas de gasolina. Los pozos son de propiedad privada y comunal, y los ríos propiedad de la Nación (acceso abierto).

Para el abastecimiento de agua de uso doméstico y pecuario, el municipio Chila de la Sal dispone de fuentes de propiedad privada y comunal como pozos tipo noria, escorrentías, bordos y una presa. Uno de los pozos se encuentra a orillas del río Mixteco, aproximadamente a $15 \mathrm{~km}$ de la comunidad. Para conducir el agua se instalaron tres bombas a diferente distancia. Una característica es que en el centro de la comunidad existe un manantial de agua salina que es aprovechado para producir sal.

El municipio de Tulcingo del Valle para abastecerse de agua para el hogar y para la ganadería dispone de fuentes de propiedad privada y comunal, como pozos tipo noria, bordos y ollas de tierra para la cosecha de agua de lluvia, un arroyo y escurrimientos de barrancas. En este municipio se encuentra un "ojo de agua" dentro del ejido de la comunidad vecina llamada Yetla, localizada aproximadamente a dos kilómetros. Esta fuente de agua de acceso colectivo beneficia a varias comunidades, entre las que se encuentra El Progreso, Loma Bonita, Francisco Villa, Los Caracoles, Olomatlán y Yetla.

En el municipio de Piaxtla, la comunidad de Atempa es la mejor ubicada al margen del Río Mixteco (propiedad de la Nación), que le permite acceder al agua para uso doméstico, consumo para el ganado, riego wells, wells with waterwheels, and currents (aguaderos) of private property and communal property.

For water supply for the household and for livestock in San Pablo Anicano, they use deep wells, wells with waterwheels, runoffs, one dam, jagüeyes and bordos to capture rainwater, both of individual property and of communal property.

In the municipality of Tecomatlán the four communities under study have a privileged location on the banks of the Acateco and Mixteco Rivers, which in addition allows good water supply for domestic use, for the livestock and to sow irrigation crops on the banks of both rivers, using wells and gasoline pumps. The wells are of private and communal property, and the rivers are property of the Nation (open access).

For the water supply of domestic and livestock use, the municipality of Chila de la Sal has sources of private and communal property such as wells with waterwheels, runoffs, bordos and one dam. One of the wells is located on the bank of the Mixteco River, approximately at a distance of $15 \mathrm{~km}$ from the community. To transport the water, three pumps were installed at different distance. One characteristic is that in the center of the community there is a salt water spring that is used to produce salt.

The municipality of Tulcingo del Valle has sources of private and communal property for its water supply for the household and livestock production, such as wells with waterwheels, bordos, and earth tanks for the harvest of rainwater, one stream and runoffs from ravines. In this municipality there is an ojo de agua (spring) inside the ejido of the neighboring community called Yetla, located approximately two kilometers away. This water source of collective access benefits several communities, among which there are El Progreso, Loma Bonita, Francisco Villa, Los Caracoles, Olomatlán and Yetla.

In the municipality of Piaxtla, the community of Atempa is the best located on the margin of the Mixteco River (property of the Nation), which allows access to water for domestic use, consumption for the livestock, agricultural irrigation on the river bank, fishing and recreation. In addition, there is a well with waterwheel of communal property for domestic use managed by a drinking water committee, in charge of collecting the payment that each family must make for the service, as well as verifying the good functioning of the well and the water distribution 
agrícola al margen de río, pesca y recreación. Además, existe un pozo tipo noria de propiedad comunal para uso doméstico administrado por un comité de agua potable, encargado de recuperar el pago que cada familia debe aportar por el servicio, además de verificar el buen funcionamiento del pozo y de la distribución del agua en cada toma. Loma Bonita y Yetla (y otras comunidades) comparten el agua de escurrimientos que se almacenan en un depósito llamado "La Pila", en la que existen derechos y reglas intercomunitarias con obligaciones mutuas, como señala Boelens (2009), y Santa María tiene un pozo profundo, pozos tipo noria y bordos que permite la siembra de riego en pequeñas áreas.

Lo anterior muestra la diversidad de fuentes de agua (con pequeños volúmenes) que existen en el territorio, tanto superficial como subterránea, que se usa para fines domésticos, abrevadero de animales, siembra de cultivos y, en algunos casos, para la pesca y recreación. El "uso" puede ser visto en el sentido de disfrute de algún tipo de beneficio (Hunt, 1998, citado en Ribot y Peluso, 2003).

El derecho al uso del agua está relacionado con la propiedad del espacio natural (familiar o individual, comunitaria o comunal y Estatal) y a la propiedad de la fuente del agua (acceso privado, comunal y abierto) (Cuadro 2).

Los usuarios establecen diferentes estrategias para el acceso al agua en función de sus recursos, capacidades y normas internas adoptadas para el acceso al recurso de propiedad comunitaria o comunal, como la supervisión y conservación de la fuente de agua, el acceso a todos los habitantes, el trabajo colectivo, la cooperación económica, en caso necesario, la defensa de la fuente y del agua, la negociación con actores institucionales, la administración de dinero, el desempeño de cargos, la asistencia a reuniones, etcétera.

Para obras comunitarias con participación del Estado (recursos públicos) se acuerda la conformación de un comité de obra que se encarga de la gestión, supervisión de la construcción, organización del trabajo, administración de recursos económicos, mediación de conflictos, etcétera, hasta la culminación de la obra. En su caso, este comité continúa por un periodo hasta que la obra esté en funcionamiento.

Para la gestión del agua del servicio público también se forman comités de agua con funciones como: vigilancia de la fuente y la infraestructura, administración de los recursos económicos, distribución del agua, in each tap. Loma Bonita and Yetla (and other communities) share the water from runoffs that are stored in a deposit called "La Pila", where there are intercommunity rights and regulations with mutual obligations, as Boelens (2009) points out, and Santa María has a deep well, wells with waterwheels, and bordos that allow irrigation farming in small areas.

This shows the diversity of water sources (with small volumes) present in the territory, both superficial and underground, that are used for domestic purposes, for animal drinking troughs, crop farming and, in some cases, for fishing and recreation. The "use" can be seen in the sense of enjoying some sort of benefit (Hunt, 1998, cited in Ribot and Peluso, 2003).

The right to water use is related to the property of the natural space (family or individual, community or communal, and State) and to the ownership of the water source (private, communal and open access) (Table 2).

The users establish different strategies to gain access water in function of their resources, capacities and internal norms adopted for access to the resource of community or communal property, such as the supervision and conservation of the water source, access for all inhabitants, collective work, economic cooperation, in the necessary case, defense of the source and water, negotiation with institutional actors, money administration, performance of duties, attendance to meetings, etc.

For community works with participation of the State (public resources), the conformation of a works committee is agreed upon, which is in charge of the management, supervision of construction, organization of work, administration of economic resources, mediation of conflicts, etc., until the culmination of the work. In this case, this committee continues for some time until the work is functioning.

For water management of the public service, water committees are also formed with functions such as: vigilance of the source and infrastructure, administration of economic resources, distribution of water, charges, allocation of tasks, etc. This is more common in works such as deep wells and deposits for the extraction of water from the river or ravines.

\section{Strategies of water appropriation}

In communities that do not have water service in households (public network), the families, 
Cuadro 2. Propiedad del espacio natural, derechos y usos del agua en municipios de la región Mixteca Baja de Puebla, México. Table 2. Ownership of the natural space, rights and uses of water in municipalities of the low Mixteca region of Puebla, México.

\begin{tabular}{llll}
\hline \multicolumn{1}{c}{$\begin{array}{c}\text { Propiedad del } \\
\text { espacio físico }\end{array}$} & \multicolumn{1}{c}{$\begin{array}{c}\text { Propiedad de la } \\
\text { fuente de agua }\end{array}$} & \multicolumn{1}{c}{$\begin{array}{c}\text { Derecho al } \\
\text { uso del agua }\end{array}$} & Uso del agua \\
\hline $\begin{array}{l}\text { Familiar o individual: } \\
\text { Parcela o predio donde se } \\
\text { localiza la fuente de agua }\end{array}$ & $\begin{array}{l}\text { Privada (familiar) } \\
\text { Acceso privado: Pozo tipo noria, } \\
\text { ojo de agua, aguaje, etcétera }\end{array}$ & $\begin{array}{l}\text { Individual: Un solo usuario } \\
\text { utiliza el agua de una fuente de } \\
\text { su propiedad }\end{array}$ & $\begin{array}{l}\text { Doméstico, pecuario o } \\
\text { agrícola }\end{array}$ \\
$\begin{array}{l}\text { Comunitaria o comunal: } \\
\text { Cerro, barranca, campo } \\
\text { para pastoreo, arroyo, etc. } \\
\text { donde se localiza la fuente } \\
\text { de agua }\end{array}$ & $\begin{array}{l}\text { Acceso colectivo: Pozo profundo, } \\
\text { pozo tipo noria, manantial, } \\
\text { arroyo, jagüey, bordos, presas, } \\
\text { aguajes, ojos de agua, cárcamo, } \\
\text { etcétera }\end{array}$ & $\begin{array}{l}\text { Colectiva: Diferentes usuarios } \\
\text { utilizan el agua de la misma } \\
\text { fuente de propiedad comunal }\end{array}$ & $\begin{array}{l}\text { Doméstico, pecuario, } \\
\text { agrícola, acuícola y } \\
\text { producción de sal }\end{array}$ \\
$\begin{array}{l}\text { Área o zona } \\
\text { federal (Estado) }\end{array}$ & Acceso abierto: ríos & $\begin{array}{l}\text { Individual y colectiva: } \\
\text { Diferentes usuarios utilizan } \\
\text { el agua de la misma fuente } \\
\text { propiedad de la Nación }\end{array}$ & $\begin{array}{l}\text { Doméstico, pecuario, } \\
\text { agrícola, acuícola, pesca y } \\
\text { recreación }\end{array}$ \\
\hline
\end{tabular}

*Artículo 27 de la Constitución política de los Estados Unidos mexicanos: la Nación tiene la propiedad de las tierras y aguas comprendidas dentro de los límites del territorio nacional y tiene el derecho de transmitir el dominio a los particulares, constituyendo la propiedad privada (DOF, 1917). Article 27 of the Political Constitution of México: the Nation has the property of the lands and water included within the limits of the national territory and has the right to transmit the dominion to the particulars, constituting private property (DOF, 1917).

Fuente: elaboración propia con información de campo. Source: authors’ elaboration with field information.

cobros, asignación de tareas, etcétera. Esto es más común en obras como pozos profundos y depósitos para la extracción del agua del río o barrancas.

\section{Estrategias de apropiación del agua}

En comunidades que no disponen de servicio de agua en su domicilio (red pública) las familias, en particular mujeres y niños, tienen que cargarla en recipientes desde una fuente, o de camiones cisterna, haciendo varios recorridos por día, dedicando horas a esta tarea cotidiana, provocando que los niños pierdan clases, y hombres y mujeres descuiden otras actividades (Antón, 1996).

Ante problemas de escasez de agua para todos los usos, la población accede a los recursos hídricos de cerros, barrancas, ríos, arroyos, manantiales, escurrimientos y cosecha de agua de lluvia, y para su almacenamiento y apropiación construye diferentes obras de uso familiar y colectivo: pozos profundos, pozos tipo noria, bordos, presas y jagüeyes. Estas diferentes formas de gestión implican acuerdos familiares, comunitarios y regionales, como señalan Toledo y Argueta (1993), y son comunes en diferentes regiones y comunidades rurales. particularly women and children, have to carry it in containers from a source, or from cistern trucks, making several rounds per day, devoting hours to this daily task, causing children to lose school classes, and men and women to neglect other activities (Antón, 1996).

Facing water scarcity problems for all uses, the population gains access to water resources from hills, ravines, rivers, streams, springs, runoffs, and by harvesting rainwater; and for its storage and appropriation they build different works of family and collective use: deep wells, wells with waterwheels, bordos, dams and jagüeyes. These different ways of management imply family, community and regional agreements, as Toledo and Argueta (1993) point out, and are common in different rural regions and communities.

Water supply is based on traditional and autochthonous practices to raise and maintain social participation (CNUMAD, 1998). In the low Mixteca region of Puebla, in order to obtain water for the household, families use different means of transportation; $76.5 \%$ (169) of the families carry 
El abastecimiento de agua está basado en prácticas tradicionales y autóctonas para elevar y mantener la participación social (CNUMAD, 1998). En la mixteca baja de Puebla, para proveerse de agua para el hogar, las familias utilizan diferentes medios de transporte; $76.5 \%$ (169) de las familias acarrea agua y solo $23.5 \%$ (52) seńaló que no lo hace, ya que disponen de la red pública o se encuentran cerca de una fuente de agua (río, arroyo o pozo). Los principales medios utilizados son: fuerza humana (a pie), tracción animal (burro), tracción motriz (en camioneta y en camión cisterna -compra-) y la combinación de todos estos (Ocampo y Villarreal, 2014). Los principales medios de transporte son el burro y el acarreo a pie.

El agua para beber y cocinar se provee por los siguientes medios: agua de garrafón, entubada (red pública), pozo profundo o noria, río y arroyo, y agua de la lluvia. La estrategia es usar una fuente o la combinación de varias, tanto de propiedad y acceso individual (familiar) como de propiedad comunal y acceso colectivo, como se describe a continuación:

\section{Agua potable de la red pública (agua entubada)}

Del total de familias, $59.7 \%$ (132) tiene agua entubada. La mitad de las familias (50.8 \%) tienen como fuentes pozos profundos y la otra mitad $(49.2 \%)$ recibe agua de pozos noria y río o arroyos. De acuerdo con la clasificación de la UNICEF y la OMS (2004), son fuentes de suministro de agua potable no mejoradas. No aseguran un nivel de calidad y funcionalidad de los servicios (principalmente conexiones domiciliarias) (Jouravlev, 2004).

El agua de la red pública se distribuye por tiempo. En promedio, las familias reciben 1.4 horas cada 3.9 días. El acceso es muy irregular; $90.2 \%$ (119) tiene agua todo el ańo, mientras que $9.8 \%$ (13) solo tiene parte del ańo; la época de mayor escasez es entre enero y mayo.

El agua entubada que llega a cada hogar tiene diferentes usos, dependiendo de las necesidades de la familia y el volumen disponible. Los usos asignados son: consumo humano (beber y cocinar), aseo personal (baño), lavar ropa, lavar trastes, riego de plantas (macetas y pequeños espacios), consumo animal y elaboración de queso; 8.3 \% (11 familias) usa el agua en las siete actividades; $100.0 \%$ (132) aprovecha el agua en seis (excepto en la elaboración de queso); water and only $23.5 \%$ (52) mentioned that they do not, since they have access to the public network or are close to a water source (river, stream or well). The main means used are: human strength (walking), animal traction (donkey), motor traction (by van and cistern truck -purchasing-), and a combination of all these (Ocampo and Villarreal, 2014). The principal means of transportation are the donkey and carrying on foot.

The water to drink and cook is supplied by the following means: bottled water, piped water (public network), deep well or waterwheel, river and stream, and rainwater. The strategy is using a source or a combination of many, both of individual property and access (family) and of communal and collective property and access, as described next:

\section{Drinking water from the public network (piped water)}

Of the total families, $59.7 \%$ (132) has piped water. Half of the families (50.8 \%) have deep wells as sources of water, and the other half $(49.2 \%)$ receives water from wells with waterwheels and river or streams. According to the UNICEF and WHO (2004) classification, they are unsanitized drinking water supply sources. They do not ensure a level of quality and functionality of the services (primarily household connections) (Jouravlev, 2004).

Water from the public network is distributed by time. In average, families receive 1.4 hours every 3.9 days. Access is quite irregular; $90.2 \%$ (119) has water all year long, while $9.8 \%$ (13) only has it part of the year; the time of greatest scarcity is between January and May.

Piped water that reaches each household has different uses, depending on the needs of the family and the volume available. The uses assigned are: human consumption (drinking and cooking), personal washing (bath), washing clothes, washing dishes, plant irrigation (pots and small spaces), animal consumption and cheese elaboration; $8.3 \%$ (11 families) use water in the seven activities; $100.0 \%$ (132) takes advantage of water in six (with the exception of cheese elaboration); $37.9 \%$ (50) use it in five activities (except for human consumption and cheese elaboration); and $5.3 \%$ (7) to wash clothes, wash dishes, personal washing and plant irrigation. Those that do not use water for 
$37.9 \%$ (50) la utiliza en cinco actividades (excepto para consumo humano y elaboración de quesos); y $5.3 \%$ (7) para lavar ropa, lavar trastes, aseo personal y riego de plantas. Las que no usan el agua para el consumo humano se proveen de agua que compran de garrafón.

\section{Compra de agua de garrafón}

De las familias $38.1 \%$ compran agua de garrafón de 19 litros. En promedio, el consumo por familia es de 6.6 garrafones por semana, lo que indica un consumo semanal de 25.1 litros per cápita (3.6 litros per cápita por día). El costo por garrafón es de $\$ 14.00$ en promedio, lo que representa un gasto de $\$ 92.40$ por semana y se compra todo el año. Básicamente, el agua se utiliza para beber y para la preparación de alimentos. Vázquez et al. (2014) reportan que las mujeres de Colonia Veracruz y San Pedrito en el estado de Hidalgo compran entre uno y cuatro garrafones, con un gasto promedio de $\$ 27.00$ semanales por familia.

\section{Trabajo humano (acarreo a pie)}

El acarreo de agua se realiza de fuentes de propiedad comunal de acceso colectivo, como pozos tipo noria, ríos y barrancas; ocasionalmente de fuentes de propiedad privada. Esta se realiza todo el año, aumentando la intensidad en los meses de marzo, abril y mayo; 54 familias acarrean agua a pie. Las distancias son variables: $31.5 \%$ (17 familias) recorren distancias entre 10 y 100 metros, $37.0 \%$ (20) caminan entre 101 y 1000 metros, y $31.5 \%$ (17) entre 1001 y 2500 metros. Respecto al tiempo empleado en ida y vuelta, $79.6 \%$ (43) invierte entre cinco y 30 minutos, y $20.4 \%$ (11) emplea entre 40 y 90 minutos. La OMS recomienda que la fuente de agua debe encontrarse a menos de 1000 metros del hogar y el tiempo de desplazamiento no debería superar los 30 minutos ida y vuelta (Naciones Unidas, 2010b).

Las distancias recorridas y los tiempos consumidos para el acarreo de agua son semejantes a los que ocurren en otras regiones; en Pozuelos, municipio de Chamula, Chiapas, en periodos de escasez de agua en la red, los integrantes de las familias y más las mujeres dedican entre dos y seis horas diarias (Soares, 2006). Las mujeres en Pudukuppam, India deben caminar entre uno y dos kilómetros para obtener agua potable y en Malwa, India; los residentes se desplazan a una human consumption are supplied by water that they purchase bottled.

\section{Purchasing bottled water}

A percentage of $38.1 \%$ of families purchase bottled water 19-liter demijohns. In average, the consumption per family is 6.6 demijohns per week, which indicates a weekly consumption of 25.1 liters per capita (3.6 liters per capita per day). The cost per demijohn is $\$ 14.00$ in average, representing an expense of $\$ 92.40$ per week and they purchase it all week. Basically, water is used for drinking and for food preparation. Vázquez et al. (2014) report that women from Colonia Veracruz and San Pedrito in the state of Hidalgo purchase between one and four demijohns, with an average expense of $\$ 27.00$ weekly per family.

\section{Human work (carrying on foot)}

Water carrying is performed from sources of communal property of collective access, such as wells with waterwheels, rivers and ravines; occasionally, from sources of private property. It is done throughout the year, with the intensity increasing during the months of March, April and May; 54 families carry water on foot. The distances are variable: $31.5 \%$ (17 families) travel distances between 10 and 100 meters, $37.0 \%$ (20) walk between 101 and 1000 meters, and $31.5 \%$ (17) between 1001 and 2500 meters. With regards to time used in coming and going, $79.6 \%$ (43) invest between five and 30 minutes, and $20.4 \%$ (11) use between 40 and 90 minutes. The WHO recommends that the source of water should be at a distance of 1000 meters or less from the household and the time of travel should not exceed 30 minutes in coming and going (Naciones Unidas, 2010b).

The distances travelled and the times consumed for water carrying are similar to the ones that take place in other regions; in Pozuelos, municipality of Chamula, Chiapas, during periods of water scarcity in the network, the members of the families and mostly women devote between two and six hours daily (Soares, 2006). Women in Pudukuppam, India, must walk between one and two kilometers to obtain drinking water and in Malwa, India; the residents travel an average distance of four kilometers to find it (Shiva, 2007). In Españita, Ixtacuixtla and Terrenate, 
distancia promedio de cuatro kilómetros para buscarla (Shiva, 2007). En Españita, Ixtacuixtla y Terrenate, en el estado de Tlaxcala, recorren entre 500 y 2000 metros diarios o cada tercer día (Ramírez, 2008).

La responsabilidad de acarrear agua es de toda la familia: esposa, esposo, hijas(os), nietos y suegros. $87.5 \%$ (105 familias) realiza el acarreo de agua en familia y $12.5 \%$ (15) se ejerce en forma individual (esposa, esposo o hijos(as). Cada familia acarrea en promedio 150 litros por día. Para hacerlo utilizan el cántaro de barro (20 l) o de lata $(20 \mathrm{l})$, cubeta (entre 10 y $20 \mathrm{l})$ y botes $(20 \mathrm{l})$. Hacen de dos a tres viajes por día; cada persona transporta entre 20 y 40 litros por viaje. Considerando 2.5 viajes por día de 30 litros cada uno, cada persona provee de 75 litros de fuentes de acceso comunitario.

Acarrear agua es una actividad cotidiana de la familia en muchas regiones de México; sin embargo, en muchos lugares la participación de la mujer (esposa) y los hijos (niños y niñas) es mayor. Soares (2006; 2007) reporta este fenómeno en una comunidad indígena en los Altos de Chiapas, al igual que Ramírez (2008) en comunidades de Tlaxcala. La mujer conoce más las necesidades de agua del hogar (Soares, 2007), por lo que su rol en la provisión es fundamental y resultan ser las más afectadas cuando falta el líquido (Domínguez et al., 2013), sobre todo en zonas de degradación ambiental y alta migración de mano de obra masculina donde la mujer asume las responsabilidades; entre éstas el acarreo de agua (Naciones Unidas, 2005).

\section{Energía animal (acarreo en burro)}

Algunas familias (132) utilizan al burro como medio de transporte. Por viaje, $67.4 \%$ (89) emplea un burro; $29.5 \%$ (39), dos; $2.3 \%$ (3), tres; y $0.8 \%$ (1), cuatro. Asimismo, $69.4 \%$ (93) realiza entre uno y cuatro viajes por día. Considerando que cada animal transporta 60 litros por viaje y hace dos viajes al día en promedio, entre los dos animales proveen a la familia de 240 litros diarios.

Utilizan como depósitos el cántaro de barro (20 l), el bote de lata (20 l) y el cubo (20 l). $11.2 \%$ (15 familias); pagaron entre $\$ 5.00$ y $\$ 50.00$ (promedio $\$ 17.00)$ por un viaje de agua en burro. La responsabilidad del acarreo en animal es compartida: $80 \%$ de las familias se acompañaron y $20 \%$ realiza el viaje en forma individual (solo la esposa, esposo, hijos. Las distancias y los tiempos son los mismos que el acarreo in the state of Tlaxcala, they travel between 500 and 2000 meters daily or every third day (Ramírez, 2008).

The responsibility for carrying water falls on the whole family: wife, husband, children, grandchildren and in-laws. A percentage of $87.5 \%$ (105 families) carry water as a family, and $12.5 \%(15)$ is done individually (wife, husband or children). Each family carries in average 150 liters per day. To do it, they use a clay (20 l) or tin (20 l) jugs, buckets (between 10 and $20 \mathrm{l}$ ), and pails (20 l). They perform two to three runs per day; each person transports between 20 and 40 liters per run. Considering 2.5 runs of 30 liters each per day, each person supplies 75 liters from sources of community access.

Carrying water is a daily activity of families in many regions of México; however, in many places the participation of the woman (wife) and children (boys and girls) is higher. Soares (2006; 2007) reports this phenomenon in an indigenous community in the Chiapas Highlands, just like Ramírez (2008) in communities of Tlaxcala. Women understand the water needs in the household (Soares, 2007), so her role in provision is fundamental and they are the ones most affected when there is a lack of the liquid (Domínguez et al., 2013), particularly in zones of environmental degradation and high masculine labor migration where the woman takes on responsibilities, among these carrying water (Naciones Unidas, 2005).

\section{Animal energy (carrying by donkey)}

Some families (132) use the donkey as a means of transport. For each run, $67.4 \%$ (89) use a donkey; $29.5 \%$ (39), two; $2.3 \%$ (3), three; and $0.8 \%$ (1), four. Likewise, $69.4 \%$ (93) performs one to four runs per day. Considering that each animal transports 60 liters per run and makes two runs per day in average, two animals provide the family with 240 liters daily.

They use as deposits clay jug (20 l), tin can (20 1), and pail $(201)$. Of the families, $11.2 \%$ (15 families) paid between $\$ 5.00$ and $\$ 50.00$ (average $\$ 17.00$ ) for a run of water by donkey. The responsibility of carrying by animal is shared: $80 \%$ of the families were accompanied and $20 \%$ performs the run individually (only the wife, husband, children). The distances and times are the same than carrying on foot, since they refer 
a pie, ya que se refieren a las mismas fuentes de propiedad comunal y acceso colectivo.

Diferentes comunidades con déficit de agua acarrean a lomo de burro como en Ojo de Agua, Puebla (comunidad indígena náhuatl); los burros cargan hasta 120 litros por viaje (Flores, 2012).

\section{Tracción motriz (abastecimiento en camioneta)}

De las familias, 40 acarrean agua en camioneta. Realizan entre uno y hasta cinco viajes semanales; $55.0 \%$ (22) hace un viaje; $35.0 \%$ (14), dos; y $10.0 \%$ (4) de tres a cinco. La cantidad de agua trasportada semanalmente varía de 200 a 6000 litros por familia, con un promedio de 1978.8 litros por semana, equivalente a 282.7 litros por día por familia. Para acarrear agua se utilizan: tinaco rotoplas (1100 l), tonel de plástico (100 l) y tonel de fierro (200 1), y algunos utensilios de menor capacidad (20 1); 22 familias pagaron el servicio de camioneta con un costo entre $\$ 20.00$ y $\$ 200.00$ (promedio $\$ 113.00)$. La época de mayor acarreo es entre marzo y junio.

\section{Tracción motriz (abastecimiento en camión cisterna)}

De las familias 47 compraron agua de camión cisterna o pipa. El número de camiones pipas compradas varió de seis al año hasta uno por semana. $42.6 \%$ (20 familias) compró entre uno y dos cada mes; $21.3 \%$ (10), entre uno y dos por quincena; $19.1 \%$ (9), entre uno y cuatro al año; y $17.0 \%$ (8) hicieron compras variables: de uno a dos por semana, de uno a dos cada dos meses, y de tres a cinco cada tres meses. El volumen total comprado anualmente por familias es de 78095.7 litros, lo que equivale a 214.0 litros por día por familia. La capacidad del camión cisterna es de 3000 litros (también existe de 10000 litros, pero las familias compran parte del volumen del agua de acuerdo con su capacidad de almacenamiento), con costos de $\$ 120.00$ a $\$ 300.00$. El agua se consume en un periodo de 15 días a tres meses. Para depositar el agua utilizan tinacos rotoplas, (1 100 l), cisternas cuadradas (de 500 a 5000 l), tonel de fierro (200 l), tonel de plástico (100 l) y cubetas (20 l).

Los camiones cisterna utilizan fuentes de propiedad privada y comunal de acceso comunitario y privado localizados en Tehuitzingo, Ahuehuetitla, Palomas, Chinantla, Piaxtla, Acatlán, Amatitlán, to the same sources of communal property and collective access.

Different communities with water deficit carry water on the donkey back as in Ojo de Agua, Puebla (indigenous Náhuatl community); the donkeys carry up to 120 liters per run (Flores, 2012).

\section{Motor traction (supplying by van)}

Of the families, 40 carry water in a van. They perform between one and up to five runs weekly; $55.0 \%$ (22) make one run; $35.0 \%$ (14), two; and $10.0 \%$ (4) from three to five. The amount of water transported weekly ranges from 200 to 6000 liters per family, with an average of 1978.8 liters per week, equivalent to 282.7 liters per day per family. In order to carry water the following are used: rotoplas water tank (1100 l), plastic barrel (100 l) and iron barrel (200 l), and some utensils of lower capacity (20 l); 22 families paid the van service with a cost of between $\$ 20.00$ and $\$ 200.00$ (average $\$ 113.00$ ). The season of higher transport is between March and June.

\section{Motor traction (supplying by cistern truck)}

Of the families, 47 purchased water from a cistern truck or tanker. The number of tanker trucks purchased varied from six per year up to one per week. A percentage of $42.6 \%$ (20 families) bought between one and two each month; $21.3 \%$ (10), between one and two per fortnight; $19.1 \%$ (9), between one and four per year; and $17.0 \%$ (8) made variable purchases: from one to two per week, from one to two every two months, and from three to five every three months. The total volume purchased annually by families is 78095.7 liters, which is equivalent to 214.0 liters per day per family. The capacity of the cistern truck is 3000 liters (there are also some of 10000 liters, but the families share part of the water volume according to their storage capacity), with costs of $\$ 120.00$ to $\$ 300.00$. The water is consumed in a period of 15 days to three months. To deposit water they used rotoplas water tanks (1 $100 \mathrm{l})$, square cisterns (500 to $5000 \mathrm{l}$ ), iron barrels (200 l), plastic barrels (100 l) and pails (20 l).

The cistern trucks use sources of private and communal property and community and private access located in Tehuitzingo, Ahuehuetitla, Palomas, Chinantla, Piaxtla, Acatlán, Amatitlán, San Jerónimo 
San Jerónimo Xayacatlán y Chila de la Sal; $72.2 \%$ (39 familias) desconoce la fuente de agua; $27.8 \%$ (15) sabe que es de pozo profundo; $83.3 \%$ (45) considera que es agua limpia; y $16.7 \%$ (9), que no es de buena calidad, clasificadas como fuentes de suministro de agua potable no mejoradas, de acuerdo con la UNICEF y a la OMS (2004).

\section{Cosecha de agua de lluvia}

La recolección de agua de lluvia es una práctica antigua usada sobre todo por sociedades localizadas en zonas áridas y semiáridas. Ante problemas de escasez es una buena opción tecnológica para proveer agua para el consumo humano a nivel familiar, para los animales y para la agricultura (Anaya, 2010).

En la región de estudio la cosecha de agua de lluvia es una práctica que realizan las familias durante el periodo de mayo a agosto. Conectan mangueras de plástico a los techos de las casas y las conducen a diferentes depósitos para su almacenamiento. Los más utilizados son toneles de fierro $(200 \mathrm{l})$, toneles de plástico (100 l), tinacos rotoplas (1 $100 \mathrm{l})$, tanques o cisternas de cemento, piedra y block (entre 500 a $5000 \mathrm{l}$ ), botes (20 l), tinas (30 l), ollas (10 l), cubetas (entre 10 y $20 \mathrm{l}$ ), y todo tipo de artefacto que sirva para almacenar agua. Estudios realizados en Portezuelos, Chiapas testifican que durante la temporada de lluvias casi toda la gente recoge agua del techo y la almacena en varios trastes (Murillo, 2005).

En las comunidades de estudio, $100 \%$ de las familias disponen al menos de un depósito. $10 \%$ (22) tiene toneles, cubetas y ollas; $9.5 \%$ (21) dispone de toneles y tinacos; $8.6 \%$ (19) tiene solo toneles; $7.7 \%$ (17) tiene toneles y tanques. Otro porcentaje igual dispone de toneles, tinacos y un tanque o cisterna, y otro número igual (17) utiliza toneles, un tanque o cisterna, cubetas y ollas. El otro 48.9 \% (108 familias) utiliza estos mismos depósitos en diferentes combinaciones, sobresaliendo los tinacos rotoplas y los toneles de fierro y de plástico. En su mayoría, el abastecimiento de tinacos y toneles a las comunidades se debe a programas públicos.

Con la implementación del Proyecto Estratégico de Seguridad Alimentaria, las propias familias autoconstruyeron (en la primera etapa) 521 cisternas de ferrocemento para la captura y almacenamiento del agua de lluvia. Los volúmenes de almacenamiento son, entre 8364 y 20044 litros, con una media de 13453
Xayacatlán and Chila de la Sal; $72.2 \%$ (39 families) ignore the source of water; $27.8 \%$ (15) know that it is from deep wells; $83.3 \%$ (45) consider it is clean water; and $16.7 \%$ (9), that it is not of good quality, classified as sources of unsanitized drinking water supply, according to UNICEF and the WHO (2004).

\section{Rainwater harvesting}

Rainwater collection is an ancient practice used particularly by societies located in arid and semiarid zones. Facing problems of scarcity, it is a good technological option to provide water for human consumption at the family level, for animals and for agriculture (Anaya, 2010).

In the study region, rainwater harvesting is a practice that families perform during the period of May to August. They connect plastic hoses to roofs of houses and lead them to different deposits for their storage. The most frequently used are iron barrels (200 l), plastic barrels (100 l), rotoplas water tanks (1 $100 \mathrm{l})$, cement, rock and block tanks or cisterns (between 500 and $5000 \mathrm{l}$ ), pails (20 l), tubs (30 l), pots (10 l), buckets (between 10 and $20 \mathrm{l}$ ), and all sorts of devices that serve to store water. Studies carried out in Portezuelos, Chiapas, give evidence that during the rainy season almost everyone collects water from the roof and in many pots (Murillo, 2005).

In the communities of study, $100 \%$ of the families have at least one deposit. A percentage of $10 \%$ (22) have barrels, pails and pans; $9.5 \%$ (21) have barrels and water tanks; $8.6 \%$ (19) have only barrels; $7.7 \%$ (17) have barrels and tanks. Another similar percentage have barrels, water tanks and a cistern tank, and another equal number (17) use barrels, a tank or cistern, pails and pots. The other $48.9 \%$ (108 families) use these same deposits in different combinations, with rotoplas water tanks and iron and plastic barrels standing out. In their majority, the supply of water tanks and barrels to the communities are dependent on public programs.

With the implementation of the Strategic Food Security Project, the families themselves built 521 ferrocement cisterns (during the first stage) for the capture and storage of rainwater. The storage volumes are between 8364 and 20044 liters per cistern, with a mean of 13453 liters per cistern. The capture area 
litros por cisterna. El área de captación principalmente son los techos de las casas y otras construcciones techadas que se conectan con una canaleta de conducción.

La cosecha de agua de lluvia por medio de cisternas de ferrocemento contribuyó a aumentar los volúmenes de agua por familia, lo que ha permitido reorganizar las estrategias para la gestión del agua, disminuyendo el acarreo, comprando más agua de camión cisterna, sembrando el huerto familiar y abrevando a los animales.

Las cisternas de ferrocemento han sido una de las técnicas más utilizadas para la captación y el almacenamiento de agua para los hogares. En África del Sur, la cosecha de aguas pluviales para el uso doméstico (con cisternas) ha proporcionado el recurso a los hogares y ha resultado una de las alternativas más prometedoras para el suministro de agua ante la creciente escasez y demanda de agua (Sazakli et al., 2007, citado en Mwenge et al., 2007).

En general, las diferentes estrategias de apropiación del agua se han construido por los propios habitantes, ajustándose a las restricciones naturales, al tiempo, al lugar, a la tecnología y a la cantidad del recurso disponible, y con reglas de provisión de trabajo, materiales y dinero (Ostrom, 2011). El acceso al agua no se da en forma natural; está condicionado por las estrategias de apropiación que desarrollan los actores sociales (Cáceres y Rodríguez, 2014).

\section{Conclusiones}

Se planteó examinar las fuentes de agua disponibles, el derecho a su uso y las estrategias de apropiación implementadas para su acceso en una condición de escasez física del agua, por lo que el debate radica en comprender la forma de relación física-ecológica y social entre la sociedad con la naturaleza para su apropiación, donde se construyen diferentes mecanismos, procesos y relaciones sociales que afectan la capacidad de la gente para beneficiarse de los recursos.

Por naturaleza, la región mixteca es limitativa en el recurso hídrico. Su clima semiárido y la orografía escarpada dificultan a las comunidades rurales acceder a fuentes de agua en cantidad y calidad para su desarrollo. Las condiciones impuestas por la naturaleza han obligado a los habitantes a reconocer cada espacio de su territorio para ubicar las fuentes naturales de agua y la construcción de fuentes artificiales para aumentar el volumen hídrico. En general, las familias reconocen is primarily the roofs of the houses and other roofed constructions that connect through a piping gutter.

Rainwater harvesting through ferrocement cisterns contributed to increasing the volumes of water per family, which has allowed reorganizing the strategies for water management, decreasing carrying, purchasing more water from cistern trucks, planting the family garden and watering the animals.

The ferrocement cisterns have been one of the most frequently used techniques for the capture and storage of water for the households. In South Africa, rainwater harvest for domestic use (with cisterns) has provided the resource to the households and has turned out to be one of the most promising alternatives for water supply in face of the growing scarcity and water demand (Sazakli et al., 2007, cited in Mwenge et al., 2007).

In general, the different strategies for water appropriation have been constructed by the inhabitants themselves, adjusting to the natural restrictions, the time, the place, the technology and the amount of resource available, and with rules for provision of work, materials and money (Ostrom, 2011). Water access does not take place naturally; it is conditioned by the strategies of appropriation that social actors develop (Cáceres and Rodríguez, 2014).

\section{Conclusions}

Examining the sources of water available, the right to their use, and the strategies of appropriation implemented for their access under conditions of physical scarcity of water was suggested, so the debate lies in understanding the physicalecological and social relationship between society and nature for its appropriation, where different mechanisms, processes and social relations are built that affect the capacity of people to benefit from the resources.

By nature, the Mixteca region is limiting on the water resource. Its semiarid climate and the steep orography make difficult for rural community to gain access to sources of water in quantity and quality for their development. The conditions imposed by nature have forced inhabitants to recognize each space of their territory to locate the natural sources of water and the construction of artificial sources to increase the water volume. In general, the families recognize the location of the various sources of superficial and underground 
la ubicación de las diversas fuentes de agua superficial y subterránea, y se han ocupado de los acondicionamientos para su extracción y disfrute.

La presencia de diversas fuentes de agua no es relativa a la disponibilidad en el hogar. El derecho al uso del agua está relacionado con la propiedad de la fuente de agua y al espacio natural donde esta se encuentra. Cuando la fuente de agua se localiza en terrenos de propiedad privada (familiar), el derecho al uso del agua es privado; es decir, el acceso solo es para la familia propietaria (en ocasiones se comparte con otras familias), y cuando la fuente de agua se encuentra en terrenos de propiedad comunitaria o comunal, el derecho es de acceso colectivo, ya sea para un grupo de familias o para toda la comunidad o para varias comunidades. Cuando es propiedad del Estado, el acceso es libre. En el derecho colectivo los usuarios establecen diferentes mecanismos para el acceso al agua en función de sus recursos, capacidades y normas o leyes consuetudinarias locales.

Sin embargo, el volumen apropiado por cada familia difiere en función de la disponibilidad de recursos materiales, económicos y humanos, provocando desigualdad social. Estas son condiciones para que cada familia implemente su estrategia de apropiación: acarreo (a pie, en burro, o en camioneta), compra en garrafón y de camión cisterna, y cosechar agua de lluvia. La tarea más difícil es acarrear agua para el uso personal y doméstico, y en esta actividad los burros resultan de mucha utilidad.

Sin embargo, el volumen disponible por familia no puede considerarse como suficiente para llevar una vida digna, sobre todo por la forma en que se accede al recurso, realidad que obliga a buscar otras estrategias colectivas con participación de los gobiernos municipal, estatal y federal, para que todas las familias tengan una fuente de agua mejorada de la red pública.

El conjunto de prácticas y acuerdos para el acceso al agua han definido el estilo de vida en las comunidades, que incluye el reconocimiento del territorio (ecosistemas) para localizar las fuentes de agua, la construcción de pequeñas obras para la captación, el uso de energía humana, animal y mecánica para su traslado y abasto, y las normas y leyes de uso para satisfacer las necesidades humanas y practicar la ganadería y la agricultura a pequeña escala.

Lo anterior demuestra la capacidad de las comunidades para enfrentar la escasez física del agua no water, and have taken care of the reconditioning for their extraction and use.

The presence of various sources of water is not relative to the availability in the household. The right to water use is related to the property of the water source and the natural space where it is found. When the water source is located in lands of private property (family), the right to water use is private; that is, access is only for the family owner (sometimes it is shared with other families), and when the source of water is located in lands of community or communal property, the right is of collective access, whether for a group of families or for the whole community or for several communities. When it is property of the State, the access is free. In the collective right the users establish different mechanisms for the access to water in function of their resources, capacities and local customary norms or laws.

However, the appropriate volume for each family differs in function of the availability of material, economic and human resources, provoking social inequality. These are the conditions for each family to implement its appropriation strategy: transport (on foot, by donkey, or by van), buying demijohns and cistern trucks, and harvesting rainwater. The most difficult task is carrying water for personal and domestic use, and donkeys are of much use in this activity.

However, the volume available per family cannot be considered sufficient to lead a dignified life, particularly because of the way in which they gain access to the resource, a reality which compels seeking other collective strategies with the participation of municipal, state and federal governments, in order for all families to have a sanitized water source from the public network.

The set of practices and agreements for water access have defined the lifestyle in communities, including the recognition of the territory (ecosystems) to locate the water sources, the construction of small works for the capture, the use of human, animal and mechanical energy for its transport and supply, and the laws and regulations of use to satisfy the human needs and to practice small-scale livestock production and agriculture.

This shows the capacity of the communities to face the physical scarcity of water not solved by the State and the adaptation to natural and social changes. For its appropriation, strategies of individual and collective action have been adopted with regulations 
resuelta por el Estado y la adaptación a los cambios naturales y sociales. Para su apropiación se han adoptado estrategias de acción individual y colectiva con reglas acordadas y respetadas por todos los apropiadores, basadas en relaciones físico-biológicas y sociales.

\section{Notas}

${ }^{1}$ La escasez física sucede cuando no hay agua suficiente para cubrir todas las demandas, incluyendo los caudales ecológicos (FAO, 2013). Physical scarcity happens when there is not enough water to cover all the demands, including the ecological volumes of water (FAO, 2013).

\section{Literatura Citada}

Anaya, Manuel. 2010. Captación o cosecha de agua de lluvia. Diseño de sistemas de captación del agua de lluvia. En Aumento de la oferta hídrica. República Dominicana: INDHRI-CEHICA. pp: 9-69.

Antón, Danilo J. 1996. Ciudades sedientas. Agua y ambientes urbanos en América Latina. Uruguay: CIID, UNESCO y Editorial NORDAN-Comunidad.

Boelens, Rutgerd. 2009. Seguridad hídrica y derechos locales. El encuentro y desencuentro entre el derecho oficial y las leyes consuetudinarias en América Latina. Agenda Social, Vol. 7, No. 1: 15-42.

Cáceres, Daniel M., y Pablo Rodríguez Bilella. 2014. Acceso y apropiación del agua en comunidades rurales pobres de $\mathrm{Ar}$ gentina central. Transformaciones y conflictos. Economía, Sociedad y Territorio, vol. XIV, núm. 45: 359-395.

Ciriacy-Wantrup, S. V. [1959] 1995. Economía y políticas de la conservación de los recursos. In: Aguilera Klink, F. (ed). Economía de los recursos naturales: un enfoque institucional. Textos de S. V. Ciriacy-Wantrup y K. W. Kapp. Fundación Argentaria. España. pp: 25-54.

CONAGUA (Comisión Nacional del Agua). 2010. Estadísticas del agua en la cuenca del Río Balsas. México: Secretaría de Medio Ambiente y Recursos Naturales (SERMANAT).

Conferencia de las Naciones Unidas sobre Medio Ambiente y Desarrollo (CNUMAD). 1998. Río 92. Programa 21-Acuerdos. España: Ministerio de Medio Ambiente.

DOF (Diario Oficial de la Federación). 1917. Constitución política de los Estados Unidos mexicanos. Publicada en el DOF del 5 de febrero de 1917. Última reforma publicada el 29 de julio de 2010.

DOF (Diario Oficial de la Federación). 2012. Decreto por el que se declara reformado el párrafo quinto y se adiciona un párrafo sexto recorriéndose en su orden los subsecuentes, al artículo $4^{\circ}$ de la Constitución Política de los Estados Unidos Mexicanos. Tomo DCCI No. 6. México: Gobierno de los Estados Unidos Mexicanos. https://www.scjn.gob.mx/normativa/analisis_reformas/Analisis\%20Reformas/00130218. pdf (7 de agosto de 2014).

Domínguez, Judith, Diana Martínez, Anabel Palacios, y Alejandra Peńa. 2013. El monitoreo social del derecho humano al agreed upon and respected by all the appropriators, based on physical-biological and social relationships.

- End of the English version -

agua y saneamiento. México: El Colegio de México e Instituto Nacional de Desarrollo Social.

FAO (Organización de la Naciones Unidas para la Alimentación y la Agricultura). 2013. Afrontar la escasez de agua. Un marco de acción para la agricultura y la seguridad alimentaria. Informe sobre temas hídricos, Roma, http://www.fao.org/ docrep/018/i3015s/i3015s.pdf (24 de septiembre de 2016). $80 \mathrm{p}$.

Flores, Oswaldo. 2012. El acarreo de agua como estrategia metodológica para una educación intercultural bilingüe. Propuesta pedagógica. Tesis de licenciatura en educación primaria para el medio indígena, Universidad Pedagógica Nacional.

Gadgil, Madhav, e Iyer Prema. 1993. La diversificación en el uso de los recursos de propiedad común en la sociedad de la India. In: cultura y manejo sustentable de los recursos naturales (volumen segundo), coordinado por Enrique Leff y Julia Carabias. México: UNAM y PNUMA. pp: 551-573.

Gerbrandy, Gerben, y Paul Hoogendam. 1998. Aguas y acequias. Los derechos al agua y la gestión campesina de riego en los Andes bolivianos. Plural editores / CID, Bolivia. 399 p.

Hernández, Raúl, y Gisela Herrerías. 2004. Tecnologías de regeneración de cuencas para la obtención de agua. El programa "agua para siempre". Puebla, México: Alternativas y procesos de participación social A. C.

IWMI (Instituto Internacional para el Manejo del Agua), y FAO (Organización de las Naciones Unidas para la Agricultura y la Alimentación). 2007. Evaluación exhaustiva del manejo del agua en agricultura. Agua para la alimentación, agua para la vida. Londres: Earthscan y Colombo: Instituto Internacional del Manejo del Agua.

INEGI (Instituto Nacional de Estadística y Geografía). 2009. Prontuario de información geográfica municipal de los Estados Unidos Mexicanos. http://mapserver.inegi.org.mx/dsist/ prontuario/index2.cfm (5 de febrero de 2014).

INEGI (Instituto Nacional de Estadística y Geografía). 2010. Compendio de información geográfica municipal 2010. http://www.inegi.org.mx/geo/contenidos/topografia/compendio.aspx (29 de julio de 2014).

INEGI (Instituto Nacional de Estadística y Geografía). 2013. Marco geoestadístico del estado de Puebla 2013.

INEGI (Instituto Nacional de Estadística y Geografía). 2016. México en cifras. Información nacional, por entidad federativa y municipio. http://www3.inegi.org.mx/sistemas/mexicocifras/default.aspx?e=32 (28 de septiembre de 2016).

INAFED (Instituto Nacional para el Federalismo y el Desarrollo Municipal). 2010. Ficha básica municipal 2010. http:// www.snim.rami.gob.mx/\# (19 de septiembre de 2014).

Jouravlev, Andrei. 2004. Los servicios de agua potable y saneamiento en el umbral del siglo XXI. Serie recursos naturales e infraestructura. CEPAL. Santiago de Chile. http://www. cepal.org/publicaciones/xml/9/19539/lcl2169e.pdf (8 de octubre de 2014).

Martínez, Joan. 1999a. Introducción a la economía ecológica. 
Rubes editorial, S. L. España. 142 p.

Martínez, Joan. 1999b. Economía, política y medio ambiente: la justicia ambiental. In: Navarro Yánez, C. J. (coord). Siglo XXI, siglo de la tierra. Medio ambiente, política y sociedad. INET. pp: 23-63.

Murillo, Daniel. 2005. Encima del mar está el cerro y ahí está el Anjel. Significación del agua y cosmovisión en una comunidad tzotzil. Jiutepec, Morelos, México: Instituto Mexicano de Tecnología del Agua.

Mwenge, Kahinda Jean-marc, Akpofure E. Taigbenu, y Jean R. Boroto. 2007. Domestic rainwater harvesting to improve water supply in rural South Africa. Physics and Chemistry of the Earth. 32: 1050-1057.

Naciones Unidas. 1948. Resolución de la Asamblea General 217 A (iii) del 10 de diciembre de 1948. Declaración Universal de los Derechos Humanos. http://www.pdh.org.gt/archivos/descargas/Educacin/Leyes\%20y\%20Tratados/declaracion_universal_derechos_humanos.pdf (13 de septiembre de 2014).

Naciones Unidas. 2002. Observación general No 15. E/C.12/2002/11. El derecho al agua (artículos 11 y 12 del Pacto Internacional de Derechos Económicos, Sociales y Culturales). http://www.solidaritat.ub.edu/observatori/general/docugral/ONU_comentariogeneralagua.pdf (13 de septiembre de 2014).

Naciones Unidas. 2005. La mujer en el 2000 y después. Mujer y agua. http://www.un.org/womenwatch/daw/public/feb05S.pdf (18 de octubre de 2014).

Naciones Unidas. 2010a. A/RES/64/292. El derecho humano al agua y el saneamiento. 3 de agosto de 2010. http:// www.un.org/en/ga/search/view_doc.asp?symbol=A/ RES/64/292\&Lang=S (13 de septiembre de 2014).

Naciones Unidas. 2010b. El derecho humano al agua y el saneamiento. http://www.un.org/spanish/waterforlifedecade/ human_right_to_water.shtml (30 de mayo de 2015).

Naciones Unidas. 2013. Objetivos del milenio. Informe de 2013. Podemos erradicar la pobreza. http://www.un.org/es/ millenniumgoals/pdf/mdg-report-2013-spanish.pdf (13 de septiembre de 2014).

Ocampo, Fletes I., y Luis A. Villarreal Manzo. 2014. Recursos hídricos, movilidad social territorial para su aprovechamiento y derecho humano al agua en comunidades de la mixteca baja de Puebla, Mexico. Ambiente y Desarrollo, 18(35), 5569.

Ostrom, Elinor. 2011. El gobierno de los bienes comunes. La evolución de las instituciones de acción colectiva. FCE, UNAM, IIS, 2011, México.

Poverty-Environment Partnership. 2006. Linking poverty reduction and water management http://dlc.dlib.indiana.edu/dlc/ bitstream/handle/10535/5151/Linking_Poverty_Reduction_2007.pdf?sequence=1 (20 de septiembre de 2016).

Ramírez, Verónica. 2008. Captación y almacenamiento de agua de lluvia a nivel familiar y su impacto en las comunidades rurales de Tlaxcala. Tesis de maestría en desarrollo rural. Co- legio de Postgraduados.

Ribot, Jesse C. and Nancy Lee Peluso. 2003. A theory of access. Rural Sociology 68(2): 153-81. http://community.eldis. org/.5ad50647/Ribot\%20and\%20Peluso\%20theory\%20 of\%20access.pdf (22 de septiembre de 2016).

Saldivar, Américo. 2007. Las aguas de la ira: Economía y cultura del agua en México ¿sustentabilidad o gratuidad? México: Universidad Nacional Autónoma.

SEMARNAT (Secretaría de Medio Ambiente y Recursos Naturales), y CONAGUA (Comisión Nacional del Agua). 2013. Estadísticas del agua en México, edición 2013. México: SEMARNAT y CONAGUA.

Shiva, Vandana. 2007. Las guerras del agua. Privatización, contaminación y lucro. México: Siglo XXI Editores.

Soares, Denise. 2006. Mujeres, agua, leña y desarrollo: estudio de caso sobre género y recursos naturales en los Altos de Chiapas. En Gestión y cultura del agua Tomo II, coordinado por Verónica Vázquez, Denise Soares, Aurelia de la Rosa y Ángel Serrano. México: IMTA y COLPOS. pp: 293-312.

Soares, Denise. 2007. Acceso, abasto y control del agua en una comunidad indígena chamula en Chiapas. Un análisis a través de la perspectiva de género, ambiente y desarrollo. Región y sociedad XIX (38): 25-50.

Toledo, Víctor M., y Arturo Argueta. 1993. Naturaleza, producción y cultura en una región indígena de México: las lecciones de Pátzcuaro. En cultura y manejo sustentable de los recursos naturales (volumen segundo), coordinado por Enrique Leff y Julia Carabias. México: UNAM y PNUMA. pp. 413-443.

Toledo, Víctor M. 2008. Metabolismos rurales: hacia una teoría económico-ecológica de la apropiación de la naturaleza. Revista Iberoamericana de Economía Ecológica. Vol. 7:1-26.

Vázquez, Verónica, María A. Pérez, y Carolina Muñoz. 2014. Desarrollo, Género y derecho humano al agua. Un estudio comparativo en Hidalgo, México. Revista Agricultura, Sociedad y Desarrollo, Vol. 11, Número 3: 295-314.

UNICEF (Fondo de la Naciones Unidas para la Infancia) y Organización Mundial de la Salud (OMS). 2004. Alcanzar los $\mathrm{ODM}$ en materia de agua potable y saneamiento. Evaluación a mitad de periodo de los progresos realizados. Suiza: UNICEF y OMS.

Von Benda-Beckmann, Franz, Keebet Von Benda-Beckmann, y Joep Spiertz. 1998. Equidad y pluralismo legal: la consideración del derecho consuetudinario en las políticas sobre recursos naturales. In: Boelens Rutgertd y Dávila Gloria, 1998. Buscando la equidad. Concepciones sobre justicia y equidad en el riego campesino. Van Gorcum. Los Países Bajos, pp: 60-74.

World Health Organization and UNICEF. 2014. Progress on drinking water and sanitation, 2014 update. Luxembourg. http://www.wssinfo.org/fileadmin/user_upload/resources/ JMP_report_2014_webEng.pdf(13 de septiembre de 2014). 